\title{
Learning to transform: The pillar that reshapes education
}

\author{
Montaudon-Tomás, I.M. ${ }^{\text {a }}$, Montaudon-Tomás, C.M. ${ }^{\text {b }}$ \\ a UPAEP (Universidad Popular Autónoma del Estado de Puebla), Puebla, México, \\ ivonne.montaudon@upaep.mx, ${ }^{b}$ UPAEP (Universidad Popular Autónoma del Estado de Puebla), \\ Puebla, México, cynthiamaria.montaudon@upaep.mx
}

\begin{abstract}
Education is the key in mankind's journey towards a free, just, and peaceful world; nevertheless, education policies fail to make the top of the lists containing government priorities. Taking into account Jacques Delors' approach regarding the Four Pillars of Education, which appeared for the first time on the 1991 UNESCO Report, and in an attempt to address the need for socially-responsible global citizens, this paper looks at learning to transform as an additional pillar that can help anchor the educational experience in all aspects of the person's life. The article explores the function of education, revises Delors' contribution, attempts to define the renewed spirit of transformation, and explores learning to transform in four distinct stages: learn, reason, act, and reflect. It is through transformation and selftransformation that the learner can alternatively become a teacher while forging relations in groups of people.
\end{abstract}

Keywords: Learning, transformation, education, global citizenship.

\section{Introduction. The educational function}

In his opening reflection on education, Jacques Delors puts in plain words that education "constitutes an indispensable instrument for humanity to progress toward the ideals of peace, freedom and social justice" (1991). In this sense, the members of the International Commission on Education for the 21st Century have identified a way to service a genuine and harmonious human growth within the role of education in the continuous development of people and societies.

Although it is still true that we can speak with a touch of disappointment about economic and social progress, it is also true that we have become more conscious about the threats that loom over us. This encourages us to participate, from the sphere of education, towards 
"sustainable human development, mutual understanding among people, and the renewal of an effectively-lived democracy" (Delors, 1991).

This development is attainable, from the ethical perspective, as long as we rise above a series of tensions the Commission has identified as part of the problems of the XXI century: The tension between global and local, universal and singular, tradition and modernity, short and long term, competence and equal opportunities, knowledge development and human capacity for assimilation; and, finally, between spiritual and material ambits.

Overcoming these tensions involves a life-long task; one in which each day represents an opportunity to develop the potential of the person, to mature his or her talents and creative capacities, to take responsibility for their own actions, and to fulfill their personal project. Permanent education consists of a continuous structuration of the human person, his/her knowledge, aptitudes, and judgment and action faculties (Delors, 1991). According to Francisco Cua, the comprehensive human development consists both on self-awareness and on personal relationships. It involves the totality of the mind, body, intelligence, sensibility, aesthetics appreciation and spirituality, starting in infancy and stretching from that point forward (Cua, n/d). Therefore, this continuous structuration covers the independent and critical way of thinking and judging of each person, which allows decision-making regarding the best courses of action in different life situations.

It is a task that acknowledges self-awareness and responsiveness to the environment while inspiring action.

\section{The four pillars of education}

In Chapter 4 of the UNESCO Report, Jacques Delors described four roads to knowledge that are inextricably linked and around which education is structured to fulfil its functions. Delors called these learnings "pillars". For each person, they will become the foundations upon which the understanding of the world will be built. The four pillars of education are:

1. Learning to know. Beyond the acquisition of structured knowledge, this pillar is about developing the abilities (competences and skills) required to understand reality. In this sense, it can be regarded both as a means and an end in life (Lee, Choi / Choil, 2017). Learning to know is about perceiving oneself as competent with the abilities cultivated; it is also and about finding satisfaction in the knowledge that has been built; finally, it is learning to think in order to magnify the human experience. 
2. Learning to do. Learning to know helps understand reality, and learning to do helps face it. It allows the person to participate in professional and social activities to tackle emerging situations. It is the pillar more closely linked to vocational training, and emphasizes the way in which education can be adapted to future work when it is impossible to foresee exactly how that work will evolve (Lee, Choi \& Choil, 2017). Learning to do helps develop selfinitiative and collaborative competences that make it easier to use information, knowledge and creativity.

3. Learning to be. This pillar is a response to the personal invitation to reflect upon one's personality and to explore personal talents. In this stage, the development of abilities is focused on personal thinking processes, judgments based on personal beliefs, and the capacity of autonomy and personal responsibility. Education must contribute to the all-round development of the individual, which is the complete fulfillment of man (Lee, Choi \&Choil, 2017). Delors (2013) suggests that this is the hardest thing to achieve in education: fully developing the creative potential of each individual in all its richness and complexity.

4. Learning to live together. This pillar is based on understanding others, recognizing interdependence, building a positive perspective of competence and preparing to deal with conflict from the standpoint of respect to pluralism and peace. It includes tolerance, respect, welcome, embrace, celebrating difference and diversity in people, and responding constructively to the cultural diversity and economic disparity around the world (UNESCO, 2012b). When we learn to live together, ties that bind people together beyond differences emerge.

Based on the idea that education is a lifelong task, it is essential to recover the concept of educational society; a notion that recognizes limitless possibilities to learn, nor only in learning communities, buy in every experience of cultural, economic and social life. With no doubt, this presents a demand that we are called to answer: We need to learn to learn (Delors, 1991).

In 1990, during the World Conference on Education for All in Jomtien, Thailand, the assembly recognized the urgency to contemplate education as an agent that enables people to "survive, fully mature their capabilities, live and work with dignity, participate in development, improve their quality of life, make well founded decisions and continue learning" (Jomtien, 1990).

Learning to learn, and continue learning... But, what for? 


\section{A renewed spirit}

Delors orientating utopia consists on ensuring that the world converges towards increased mutual comprehension, intensifying the sense of responsibility and solidarity supported upon the basis of accepting spiritual and cultural differences. In other words, we are hoping to shape citizens of the world through a conscious and active practice that must originate in schools giving place to a renewed spirit that inspires students to make a positive difference in the world: A transformational spirit.

Oxfam Education's proposal of Basic Competences for Global Citizenship recognizes Jacques Delors' perspective of the person as a whole, and enriches it through education for global citizenship, which allows to add a new pillar to the four learnings presented in the UNESCO Report, one that is aligned with building a more just world: Learning to transform (Oxfam, 2005).

Learning to transform therefore entails shaping the "renewed spirit that promotes the realization of common projects, searching for intelligent and peaceful solutions to unavoidable conflicts" (Delors, 1991) and developing the competences required to engage in responsible interactions while building a more just and sustainable world; in brief, to act in the quest of the common good, because education is a social experience.

This renewed spirit should impregnate not only the students. All the actors that conform the educational society need to deploy their abilities to contribute to the transformation: parents, principals, and the local community are also participants in this learning process. We are encountering a spirit that transforms and is transformed, making space to a society in which each member will alternatively become educator and learner (Delors, 1991).

\section{What is transformation?}

"Do not conform to the pattern of this world, but be transformed by the renewing of your mind." (Rom. 12:2)

María Moliner's Dictonary for the use of Spanish defines transformation as "giving a different form or appearance to something or someone", "transmutation in another thing", and, in the case of electricity, "changing with the help of a transformer". In the quote by the apostle Paul cited at the beginning of this section, the term employed in early Greek is metamorphosis ( $\mu \varepsilon \tau \alpha \mu o ́ \rho \varphi \omega \sigma \iota \varsigma)$, a word that the Dictionary of the Spanish Language of the Royal Spanish Academy (RAE) defines as " a move that someone or something does 
from one state to another"; and when analyzing living beings, it is a "change that they experiment during their development and that manifests itself not only in the variation of form but also in the functions and in the genre of life".

Adapting Moliner's definition to educational society, the possibility of achieving change through a transformer becomes an evident and reachable learning goal; this means, a transformational agent, a transformative leader. Considering the definition proposed by the $\mathrm{RAE}$, it is possible to assume that change is experimented throughout the development of skills but that it originates in human nature. As long as it is sustained with the adequate nutrients, the person transforms altogether; very much like the caterpillar, which is not disguised as a butterfly, but actually is one.

If transforming (and transforming oneself) depends on an important measure of the "adequate nutrients", it is also required that these nutrients are effectively assimilated because genuine transformation starts with an internal change. Learning to transform is a gradual process that emerges from a renewed state of mind, a new attitude, and culminates with the external expression of concrete activities once a series of conditions from the educational sphere are being met:

a. Searching for the truth, observing reality as it is (learning to know, stemming from conceptual contents)

b. Being conscious and contemplating reality from the perspective of the common good (learning to live together, stemming from the behavioral contents)

c. Educating in justice; reflecting on what is fair (learning to become, stemming from the attitudinal contents)

d. Identifying what is missing and rehabilitating reality (learning to do; stemming from experiential contents)

e. Finally, socializing change, sharing achievements, and moving from being a learner to being an educator.

By alternatively shifting from learner to educator, the person is called to "feel oneself with the other" (Ballesteros $\mathrm{n} / \mathrm{d}$ ). Global citizenship therefore becomes a collective action that allows to transform the world through a dynamic process, improving it to guarantee the common good. Transformational leadership emerges from a pedagogy of full participation. In this sense, Robinson (2009) acknowledges the importance of developing a sense of cultural identity in students, an idea of their place in the world so that they will be able to choose their standpoint in any scenario. 


\section{Learning to transform}

Learning to transform is supported on the postulate that people have the power to change themselves and to change things. The concept has been analyzed from the perspective of sustainable school transformation (Crossley \& Corbyn, 2010), and sustainable evelopment (UNESCO, 2012; Rieckmann, 2018).

In 2012, the UNESCO presented the Education for Sustainable Development Initiative, which included a conceptual model for ongoing, lifelong learning based on Delors' four roads to knowledge, adding an additional pillar: Learning to transform oneself and society, in the understanding that when individuals and groups gain knowledge, develop skills, and acquire new values as a result of learning, they are equipped with tools and mindsets for creating lasting change in organizations, communities, and societies.

The importance of learning to transform is based on specific claims of the newer generations; young men and women who will develop critical thinking skills and who will be able to ask themselves transcendent questions. It is a responsibility of schools to equip children and young adults with the knowledge, skills and values that will promote their participation in society.

By learning to transform, students will be able to acknowledge the complexity of global affairs and to discern the global dimension as a part of everyday life in their local surroundings. In this way, they will discover and understand their relation with the environment and the people they share the planet with (Oxfam, 2005).

Learning to transform is educating for global citizenship; it is about accompanying the development of persons who want to understand the way the world works in all aspects (environmental, cultural, economic, social and technological). Being a global citizen, the individual who learns to transform is conscious about his/her environment, realizes that he has a role in it, and is willing to take action while respecting and valuing diversity. The person we are talking about takes responsibility for his/her actions, finds social injustice offensive, and participates in community life (Oxfam, 2005).

It is possible, then, to speak about a process inspired by Mark Sanborn's potential matrix (2017) and Bustos, Hernández \& Riojas' social justice approach (2011); one that organizes learning to transform in four distinct stages that correspond to the areas outlined in Sanborn's personal development route (Learn-Reason-Act-Reflect):

1. Learn: It is based on knowing the content (topic, problem), considering it from multiple perspectives, trying to understand the causes that provoked it and the 
consequences that it would bring about. Individuals acknowledge previously established beliefs and develop cultural competence.

2. Reason: Entails a critical consideration of what can be done based on the problem, connects it to the values and global perspectives in order to understand the nature of power and action. Individuals plan actions to raise awareness and to experiment.

3. Act: Consists on planning and executing actions as a global citizen would, both individually and collectively. In the sense of praxis, it is a reflection-action about the world in order to transform it (Freire, 1986).

4. Reflect: It is based on reconsidering, questioning, celebrating and learning from actions that have been taken.

The process is also supported by Vygotsky's Theory of Sociocultural Cognitive Development (Moll, 2013), since social interaction in a context always influences learning.

\section{Final considerations}

Richard Leblanc affirms that when learning occurs, the person is transformed the moment in which synapsis and neurons form a connection and structure a thought; this transformation is notorious even in minor details such as facial features.

Learning to transform entails transcending the traditional notion of competence, including attitudes, conditions and needs; increased reliability, knowledge of disciplines, credibility, domain of relevant skills, interpersonal, communication and decision-making abilities; intelligence and intuition, all of which are immerse in a personal commitment for change (Cua, n/d).

Change will find its way when communities assume the responsibility for their own development and their innovation capacity; when we value the role of the education al society orientated towards improving the quality of life and towards achieving the common good (Delors, 1991).

To transform and to transform oneself into an agent of change or a transformational leader requires a new state of mind. This new mentality is not only about accepting different points of view or opinions, nor about the mere ability to perceive of detect something. It requires to take a stand, to show a conduct, an orientation, an attitude, and an inclination. Just as Paul exhorted the Romans: to transform oneself, one requires to be renewed "in the spirit of the mind". 
This is an open invitation to assume the knowledge of reality, stemming from the commitment to action, as a vital instrument. The change that we need and desire will only be possible if we learn to transform. The starting point for the transformation of the world and for our own transformation needs to be based on what is familiar and constant; the near and the daily, feeling one with the other to find each other and to find a way to be and to do things (Ballesteros, $\mathrm{n} / \mathrm{d}$ ).

As Paulo Freire has stated, education does not change the world, but it does change the people who will change the world (Freire, 2000).

\section{References}

Ballesteros, C. (s/f). Transformar el mundo. Universidad Pontificia de Madrid. Available online: http://www.diocesisdecanarias.es/solidaridad/mundo-nuevo-transformar-el-mundo.html

Bibles for America. (s/f). El sello del espíritu. Available online: www.biblesforamerica.cor

Bustos, B., Hernández, R., Riojas, E. (2011). "Educar para transformar: Un enfoque de justicia social en la preparación de maestros de educación bilingüe". Didac 58. Available online: http://revistas.ibero.mx/didac/articulo_detalle.php?pageNum_paginas=1\&totalRows_paginas=7\&i d_volumen $=2 \&$ id_articulo $=38 \&$ pagina $=1$

Comisión Internacional sobre la educación para el siglo XXI. (1996). La educación encierra un tesoro Informe a la UNESCO de la Comisión internacional sobre educación para el siglo XXI. Madrid. Santillana/UNESCO.

Conferencia Mundial sobre Educación para todos. (1990). Declaración Mundial sobre educación para todos: "Satisfacción de las necesidades básicas de aprendizaje". Jomtien. Available online: https://www.oei.es/historico/efa2000jomtien.htm

Crossley, D. \& Corbyn, G. (2010). Lear to transform. Developing a 21st century approach to sustainable school transformation. Glasgow, UK. Bell \& Bain.

Cua, F. (s/f) UNESCO Four Pillars of Education. Reflected and Commented in the Context of Curriculum Design. https://www.researchgate.net/publication/258139039

Delors, Jacques. (1991). "Los cuatro pilares de la educación”, en La educación encierra un tesoro. Informe a la UNESCO de la Comisión internacional sobre educación para el siglo XXI. Madrid. Santillana/UNESCO

Diccionario del uso del español María Moliner. (s/f). Versión en DVD. Barcelona. Editorial Gredos.

Freire, P. (1997). Pedagogía de la autonomía. México. Siglo XXI Editores.

(1986). La Educación como práctica de la libertad. Madrid. Siglo XXI Editores.

(2000). Pedagogy of the Oppressed. New York: Continuum. 39th Anniversary Edition. 
Intermón Oxfam. (2005). Hacia una ciudadanía global: Propuesta de competencias básicas. Informe en línea, consultado el 6 de mayo de 2019, en: http://www.intermonoxfam.org/sites/default/files/documentos/files/Hacia_Ciudadania_Global.pdf

--------, Manifiesto internacional: Educar para una ciudadanía global. http://www.intermonoxfam.org/sites/default/files/documentos/files/091224_Manifiesto_internacio nal_es.pdf

Leblanc, R. (1989) Good Teaching: The Ten Top Requirements. The Teaching Professor, Vol 12 Num. 6. York University's School of Administrative Studies. Available online: http://rleblanc.info.yorku.ca/good-teaching-the-top-10-requirements/

Lee, K., Choi, S. Y., \& Choi, U. S. (2017). A study on the meaning of the 'lifelong learning to be' implicated in the philosophy of Nietzsche. Journal of Systemics, Cybernetics and Informatics, 15(5), 27-32.

Moll, L. (2014). L. S. Vygotsky and Education. New York. Routledge.

Montaudon, I. (2013). Dimensión global: Empoderando ciudadanos del mundo en las Preparatorias Ibero (Puebla, Tlaxcala y Veracruz). Propuesta para la implementación de un programa de educación para la ciudadanía. Puebla. Universidad Iberoamericana.

Real Academia de la Lengua Española. (s/f). Diccionario de la lengua española. Online dictionary: https://dle.rae.es/?w=diccionario

Rieckmann, M. (2018) Learning to transform the workd: Key competencies in education for sustainable development. Chapter 2 In: A. Leicht, J. Heiss and W. J. Byun (eds). Issues and trends in education and sustainable development. Education on the move. UNESCO. Education 2030. Available online: https://unesdoc.unesco.org/ark:/48223/pf0000261802

Robinson, K. (2009). The element. How finding your passion changes everything. New York. Penguin Books.

Sanborn, M. (2017). The potential principle. Nashville. Thomas Nelson.

United Nations Educational, Scientific and Cultural Organization (2012). Shaping the education of tomorrow: 2012 Report on the UN Decade of Education for Sustainable Development, abridged. Paris, France: UNESCO.

(2012b). Education for Sustainable Development. Educational Sourcebook. Learning and Training tools no. 4. Available oline:

https://sustainabledevelopment.un.org/content/documents/926unesco9.pdf 